\title{
Walne Zebranie (sprawozdawczo-wyborcze) Grupy Polskiej Stowarzyszenia Prawa Międzynarodowego (I LA) \\ WARSZAWA, 13 PAŹDZIERNIKA 2017 R.
}

Dnia 13 października 2017 r. odbyło się w Warszawie Walne Zebranie Sprawozdawczo-Wyborcze Grupy Polskiej Stowarzyszenia Prawa Międzynarodowego (International Law Association).

Obrady otworzył i przybyłych na spotkanie powitał Przewodniczący Stowarzyszenia, prof. dr hab. Jerzy Menkes (SGH). Następnie na przewodniczącego Zebrania został powołany dr hab. Bartłomiej Krzan, prof. UWr, a na sekretarza dr Magdalena Półtorak (UŚ). W skład Komisji Skrutacyjnej weszli: dr Marian Banach (Krakowska Akademia im. Andrzeja Frycza Modrzewskiego), dr Wojciech Konaszczuk (UMCS), mgr Iryna Kozak (KUL).

W dalszej kolejności, po zaakceptowaniu porządku obrad, zostało zaprezentowane sprawozdanie merytoryczne z działalności Polskiej Grupy Stowarzyszenia Prawa Międzynarodowego, które przedstawiła Sekretarz Generalny ustępującego Zarządu, dr Anna Czaplińska (UŁ)․․ Sprawozdanie finansowe zreferowała dr Ewelina Cała-Wacinkiewicz (US), Skarbnik Stowarzyszenia. Następnie ze sprawozdaniem i wnioskami Komisji Rewizyjnej zapoznał uczestników Zebrania dr Tomasz Kamiński (UW).

Uczestnicy spotkania odnieśli się do przedstawionych sprawozdań i wzięli udział w dyskusji. Szczególne wyrazy podziękowania za dotychczasową działalność Zarządu skierowano pod adresem Przewodniczącego, prof. dr. hab. Jerzego Menkesa oraz Skarbnika Stowarzyszenia, dr Eweliny Cała-Wacinkiewicz. W toczącej się dyskusji wyrażono też postulaty dotyczące przyszłej działalności Stowarzyszenia. Następnie przewodniczący Zebrania zarządził głosowanie nad udzieleniem absolutorium dla dotychczasowego Zarządu. Po jego udzieleniu ogłosił możliwość zgłasza-

${ }^{1}$ A. Czaplińska, Sprawozdanie merytoryczne z działalności Grupy Polskiej International Law Association. Kadencja Zarzadu 2013-2017, „Studia Prawnicze KUL” 2017, nr 3, s. 211216. 
nia kandydatów i zarządził wybory na Przewodniczącego Polskiej Grupy ILA na czteroletnią kadencję 2017-2021.

Przewodniczącym Polskiej Grupy Stowarzyszenia Prawa Międzynarodowego na kadencję 2017-2021 został prof. dr hab. Jerzy Menkes. W dalszej części zgłoszono kandydatów do Zarządu Stowarzyszenia oraz Komisji Rewizyjnej.

Członkami Zarządu zostali: dr Ewelina Cała-Wacinkiewicz (US); dr Anna Czaplińska (UŁ); dr hab. Karol Karski, prof. UW; dr hab. Artur Kozłowski, prof. UWr; dr hab. Bartłomiej Krzan, prof. UWr; dr hab. Joanna Nowakowska-Małusecka, prof. UŚ; prof. dr hab. Anna Przyborowska-Klimczak (UMCS); dr hab. Wojciech Sz. Staszewski (KUL).

W skład Komisji Rewizyjnej weszli: dr Tomasz Kamiński (UW), dr Magdalena Słok-Wódkowska (UW), dr Kinga Stasiak (KUL).

Zarządzono przerwę w celu ukonstytuowania się władz oraz dokonania podziału obowiązków w nowo wybranym Zarządzie. Przewodniczący Polskiej Grupy ILA poinformował, że wiceprzewodniczącymi będą: dr hab. Karol Karski, prof. UW i prof. dr hab. Anna Przyborowska-Klimczak; wiceprzewodniczącą ds. naukowych dr hab. Joanna Nowakowska-Małusecka, prof. UŚ; członkami Zarządu ds. młodych naukowców dr hab. Artur Kozłowski, prof. UWr oraz dr hab. Bartłomiej Krzan, prof. UWr; Skarbnikiem dr Ewelina Cała-Wacinkiewicz; członkiem Zarządu ds. kontaktów Grupy Polskiej ILA na szczeblu międzynarodowym i krajowym dr Anna Czaplińska, a Sekretarzem Generalnym dr hab. Wojciech Sz. Staszewski. Z kolei członkowie nowo wybranej Komisji Rewizyjnej poinformowali, że jej Przewodniczącym został dr Tomasz Kamiński.

Następnie nowo wybrany Przewodniczący Polskiej Grupy ILA poinformował o planach Zarządu i działalności Polskiej Grupy w nadchodzącej kadencji 2017-2021.

* Dr hab., Katolicki Uniwersytet Lubelski Jana Pawła II. 